\title{
BRIEFING: WEST AFRICA AND ITS OIL
}

\author{
STEPHEN ELLIS
}

THE US WAR ON TERRORISM AND PREPARATIONS FOR WAR against Iraq have enormously increased the strategic value of West African oil reserves. This comes at a time when there have been massive new discoveries in offshore waters.

West Africa's offshore oil fields have been increasingly attractive to oil companies for some years, not least because, according to industry sources, the companies are often able to make higher profits per barrel than on oil from other parts of the world. The quality of Nigerian crude in particular is especially well adapted for use in US refineries. Nigeria is currently the fifth largest exporter of crude oil to the United States behind Canada (1.8 million barrels per day), Saudi Arabia (1.4 million), Mexico and Venezuela. Nigeria is currently exporting between 900,000 and one million barrels per day to the US. Angola is also an important exporter to US markets. Some 15 percent of US oil imports come from Africa. ${ }^{1}$

The shock to US strategic thinking caused by the 11 September attacks has coincided with the discovery of major new offshore oil reserves in the Gulf of Guinea region, taken broadly to include the entire sweep from Angola to Senegal. Production in Nigeria and Angola, Africa's largest oil producers, is expected to double or triple in the next 5-10 years. Apart from Congo-Brazzaville, also an established producer, major new producers that are now emerging include Equatorial Guinea and São Tomé and Príncipe. There have also been significant new offshore discoveries in Mauritania, Côte d'Ivoire, Namibia and South Africa. Most of the new reserves are in deep-sea oil fields that can now be exploited by new technology.

Spearheading the intensive lobbying in Washington on the subject of West African oil is a US-Israeli lobby, the Institute for Advanced Strategic and Political Studies. It has established a working group called the African Oil Policy Initiative Group (AOPIG). This group cites National Intelligence Council estimates to the effect that African imports will amount to 25 percent of total US imports by 2015; other official sources in the US offer higher estimates. It is expected that some $65-75$ percent of US direct investment in Africa in the next decade will be in the energy sector. The

Stephen Ellis is co-editor of African Affairs.

1. Most of the research for this article comes from interviews carried out in Washington, DC in August and September 2002, and internet research. Relevant internet articles include Keith Somerville, 'US looks to Africa for "secure oil"', BBC News Online, 13 September 2002; and 'US moves to abandon S/Arabia for Nigeria's oil', www.petroleumworld.com/story8516.htm 
marked enthusiasm for African oil in some circles in Washington is of a piece with a wish in the current US government to reduce dependence on the Middle East more generally, by developing new oil fields, such as in central Asia, and by drilling in Alaska. Central Asia, however, is a region that could soon be as volatile as the Gulf. The African oil lobby in Washington includes an interesting mix of major oil companies, pro-Israel groups, and the Congressional Black Caucus. It also appears to enjoy support in the Pentagon. Thinking in the State Department seems to be more divided, although Assistant Secretary of State for African Affairs Walter Kansteiner III is on record as an enthusiast for boosting African oil exports.

The development of oil in $\mathrm{Chad}^{2}$ is seen as an interesting precedent for some of the newer West African producers also. Among the most innovative aspects of Chadian oil production and marketing is the degree of publicprivate partnership between the World Bank Group, the government of Chad and private investors, with the World Bank joining oil companies in financing the pipeline from Chad through Cameroon to the ocean. Another important precedent is the role of the World Bank in managing royalties generated by oil production, an idea that some Washington sources are keen to extend to other oil producers in countries with a weak state apparatus. The AOPIG recommends creating a new military command in West Africa, along the lines of US Forces Korea, with a major base on São Tomé, itself now emerging as an oil producer. ${ }^{3}$ The US already gives significant support to military structures coordinated by the West African regional grouping, the Economic Community of West African States (ECOWAS), through both public and private sector cooperation. The President of São Tomé and Príncipe, Fradique de Menezes, is among several West and Central African heads of state to have discussed oil strategies with US President George W. Bush. De Menezes announced on 22 August that his country had reached agreement with the US to build a naval base in his country, although it now seems unlikely that agreement has been reached on this. ${ }^{4}$

There seems no doubt that the US interest in enhanced oil production from West Africa is likely to have a major effect on West African politics in the next few years. It will greatly increase the strategic importance of the region in general, and will doubtless raise the stakes in the national politics of a region that has become highly unstable since the outbreak of war in Liberia in December 1989. The increase in oil royalties to the governments of small island states - notably São Tomé and Príncipe and Equatorial

2. Jane Guyer, 'Briefing: the Chad-Cameroon petroleum and pipeline development project', African Affairs 101, 402 (2002), pp.109-15.

3. http://www.israeleconomy.org/strategic/africawhitepaper.pdf

4. Bush to meet Africans on naval base, oil', Washington Times, 13 September 2002. On São Tomé and Príncipe, see the article by Jędrzej Frynas, Geoffrey Wood and Ricardo Soares de Oliveira in this issue of African Affairs. 
Guinea - is likely to more or less destroy their current economic production, leaving them as rentier states in the manner of some Gulf emirates. Oil-rich governments with substantial territories in continental Africa may follow the path already taken for many years by Angola, developing a wealthy elite living in enclave settlements, and investing heavily in military forces, while effectively leaving the welfare arm of government to international humanitarian action. ${ }^{5}$ Where oil production is onshore, and most notably in Nigeria, local struggles in the actual oil-producing regions are likely to intensify. Nigeria, more than ever, seems set to emerge as the key power in West Africa and at the same time its greatest enigma. A calm and prosperous Nigeria would be a guarantor of peace and stability. An unstable Nigeria creates great tension and does nothing to fill the power vacuum apparent in the region, not least because it reminds everyone of the awful possibilities of the break-up of this vital country. Nigerian politics is at present showing a dangerous tendency to polarize around religion, at the same time as unofficial militias proliferate. Moreover, there is apparent support for Al-Qaeda in northern Nigeria.

The mixture of abundant oil and dysfunctional states in West Africa is likely to create pressure for forms of trusteeship over some of the weaker states in the region. At the moment, there are several forms of international trusteeship operating in the world, which the British diplomat Robert Cooper does not hesitate to label as 'imperialism'. One of these types of trusteeship he calls 'the voluntary imperialism of the global economy', ${ }^{6}$ which he says is 'usually operated by an international consortium through international financial institutions such as the IMF and the World Bank'. The second type is 'the imperialism of neighbours', as in Bosnia and Kosovo. West Africans may recognize this as the type of influence operated in recent years by Nigeria in Liberia and Sierra Leone, via the regional peacekeeping force ECOMOG. One may add a third variant in the form of the British presence in Sierra Leone, but this already appears to have been an anomaly in the normal conduct of international affairs.

The development of oil resources may in the near future lead to the development of a fourth form of trusteeship in countries whose governments are deemed to be weak or otherwise unacceptable. This will be a hybrid form in which trusteeship is run by a public-private partnership managed partly by the World Bank. This can be paid for from local resources, as in Chad and as in northern Iraq. The pointers seem to be towards security in such places being delegated to private security companies, some of which already have a presence in West Africa, and local

5. Cf. Christine Messiant, 'The Eduardo dos Santos Foundation: or, how Angola's regime is taking over civil society', African Affairs 100, 399 (2001), pp. 287-309.

6. Robert Cooper, 'The post-modern state', in Mark Leonard (ed.), Re-Ordering the World: The long-term implications of 11 September (The Foreign Policy Centre, London, 2002), p. 18. 
militias or vigilante forces. Interestingly, many of the latter are closely associated with traditional secret societies that are now undergoing a distinct revival. ${ }^{7}$ Oil, international partnerships and the reinvention of tradition could be elements of a future political mix.

7. Stephen Ellis, 'Les Guerres en Afrique de l'Ouest: le poids de l'histoire', Afrique contemporaine 198 (2001), pp. 51-6. 